\title{
Nocardiopsis, a New Genus of the Order Actinomycetales
}

\author{
J. MEYER \\ Zentralinstitut für Mikrobiologie und Experimentelle Therapie, Forschungszentrum für Molekularbiologie \\ und Medizin, Akademie der Wissenschaften der DDR, Jena, German Democratic Republic
}

On the basis of morphological and biochemical criteria, Actinomadura dassonvillei (Brocq-Rousseu) Lechevalier and Lechevalier, the former Nocardia dassonvillei (Brocq-Rousseu) Liegard and Landrieu, is removed from the genus Actinomadura Lechevalier and Lechevalier to a new genus, Nocardiopsis. It is proposed that this new genus harbors aerobic actinomycetes with a nocardioform substrate mycelium, an aerial mycelium, and a cell wall containing meso-2,6diaminopimelic acid but not madurose or other diagnostically important carbohydrates. The type species is Nocardiopsis dassonvillei (Brocq-Rousseu) comb. nov., for which strain IMRU 509 (= ATCC 23218) is designated as the neotype. An outline of the characters which differentiate the new genus from the genera Nocardia, Actinomadura, and Streptomyces is given.

The original strains of Actinomadura dassonvillei (Brocq-Rousseu) Lechevalier and Lechevalier were isolated by Brocq-Rousseu from mildewed grain and were described by him under the name Streptothrix dassonvillei in 1904 (not 1907 as mentioned in Index Bergeyana [3]). Some years later, Liegard and Landrieu (17) isolated from a case of conjunctivitis a microorganism which they considered to be identical to Streptothrix dassonvillei but which they assigned to the genus Nocardia. Knowledge concerning Nocardia dassonvillei was scarce until Gordon and Horan (8) discovered that the macroscopic appearance and a number of the physiological characters of $N$. dassonvillei were similar to those of Streptomyces griseus. Subsequently, Lechevalier and Lechevalier (13) described the genus Actinomadura to harbor Nocardia madurae (Vincent) Blanchard (the type species), $N$. pelletieri (Laveran) Pinoy, and N. dassonvillei (Brocq-Rousseu) Liegard and Landrieu. In the meantime, several new species of Actinomadura Lechevalier and Lechevalier have been described by several authors $(5,10,17,23,29,30,31)$. Therefore, it seems reasonable to reconsider at this time the taxonomic position of Actinomadurá dassonvillei.

The author is in full agreement with the opinion of Lechevalier et al. (14) that "actinomycetes may be classified conveniently into rather large groups, say at the generic level, by using a combination of morphological and chemical criteria." However, in the case of Actinomadura dassonvillei, there are striking differences in morphology, e.g., mode of sporulation of the aerial mycelium $(13,15)$ and the nature of the substrate mycelium, between this species and all other members of the genus
Actinomadura. Furthermore, the lack of madurose in the whole-cell hydrolysates, previously referred to by Lechevalier and Lechevalier (12, $13,15)$, is an additional character which distinguishes this species from the other Actinomadura species. Moreover, a numerical analysis of some nocardioform bacteria by Goodfellow (6) supplied further evidence that $A$. dassonvillei is not related to nocardiae or to $A$. madurae or A. pelletieri. All $A$. dassonvillei strains examined formed a homogeneous cluster at the $90 \%$ similarity level. In Goodfellow's dendrogram, there was no indication of a relationship between $A$. dassonvillei and A. madurae or $A$. pelletieri. Recently, Williams et al. (34) studied the process of spore formation by the aerial hyphae of $A$. dassonvillei to obtain further information on the characteristics of this species and to determine its relationship with other species, but they were unable to come to any definite conclusions.

This paper presents the results of a study designed to determine a suitable taxonomic niche for A. dassonvillei.

\section{MATERIALS AND METHODS}

Bacterial strains. The following strains were studied: Nocardia dassonvillei, Institute of Microbiology, the Rutgers University (IMRU) 509 (= American Type Culture Collection [ATCC] 23218); $N$. dassonvillei, Institute of Microbiology, the Rutgers University (RG) $714 ; N$. dassonvillei RG 1250 (= ATCC 23219); and Zentralinstitut für Mikrobiologie und Experimentelle Therapie, Jena, DDR, IMET 9563 , isolated from a soil sample from Lebanon. According to Gordon and Horan (8), strains RG 714 and RG 1250 were derived from infections of humans or other animals.

Media. The media used for morphological observations of the strains were ISP media $2,3,4$, and 8 (32), oatmeal-nitrate agar (27), Bennett agar, 


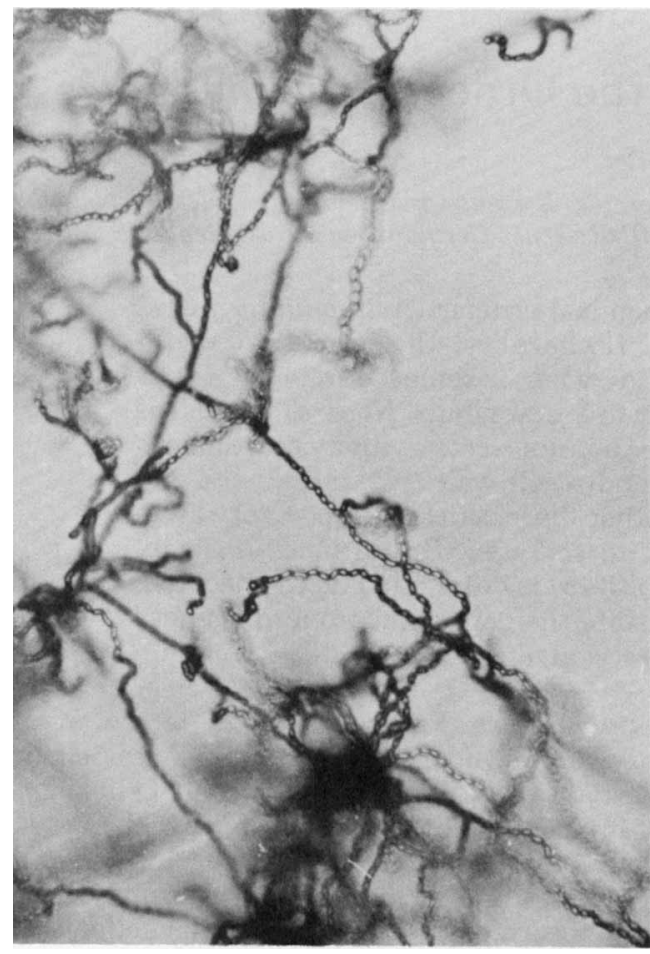

FIG. 1. Nocardiopsis dassonvillei RG 1250. Sporulating aerial mycelium. Czapek sucrose agar, 7 days. Magnification, $\times 480$.
Czapek sucrose agar, and complex organic medium 79 of Prauser and Falta (28). Physiological tests were carried out by the procedures described by Gordon (7). Carbon-source utilization was determined on ISP medium 9 with the following carbohydrates: $L$-arabinose, D-xylose, D-mannose, D-glucose, L-rhamnose, maltose, lactose, adonitol, dulcitol, $\mathrm{D}$-mannitol, $i$ inositol, D-fructose, sucrose, raffinose, and glycerol.

Biochemical tests. Cell wall analysis was carried out by the method described by Becker et al. (1), and the presence of madurose was determined by the procedure of Lechevalier (15). Other cell wall sugars were determined by the method of Murray and Proctor (21) and Mund and Venner (20), i.e., ascending chromatography with repeated exchange of the solvent. Cell wall lipid analysis was performed by the procedure described by Mordarska et al. (19).

\section{RESULTS AND DISCUSSION}

A. dassonvillei differs from the other species placed in Actinomadura not only in its morphology but also in its biochemical characteristics. Whereas the substrate mycelia of the latter are stable, the substrate mycelium of $A$. dassonvillei fragments into coccoid elements, and the fragmentation of the aerial hyphae results in elements of irregular size (Fig. 1-3). The fragmentation can proceed without interruption from the substrate mycelium to the aerial mycelium. Thus, A dassonvillei corresponds to Prauser's (25) definition of nocardioform organisms: "Actinomycetes which solely

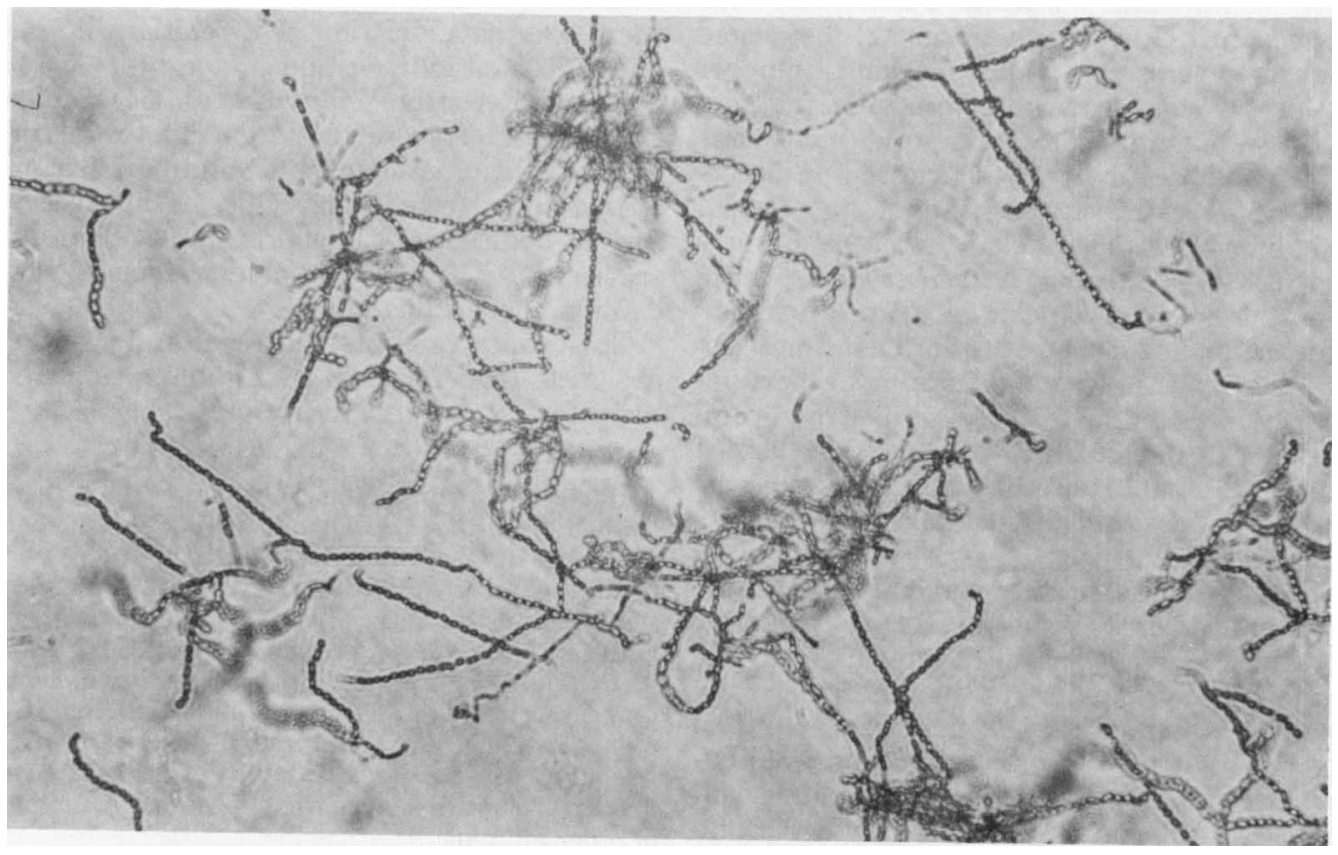

FIG. 2. Nocardiopsis dassonvillei RG 1250. Sporulating aerial mycelium. ISP medium 4, 4 weeks. Magnification, $\times 440$. 


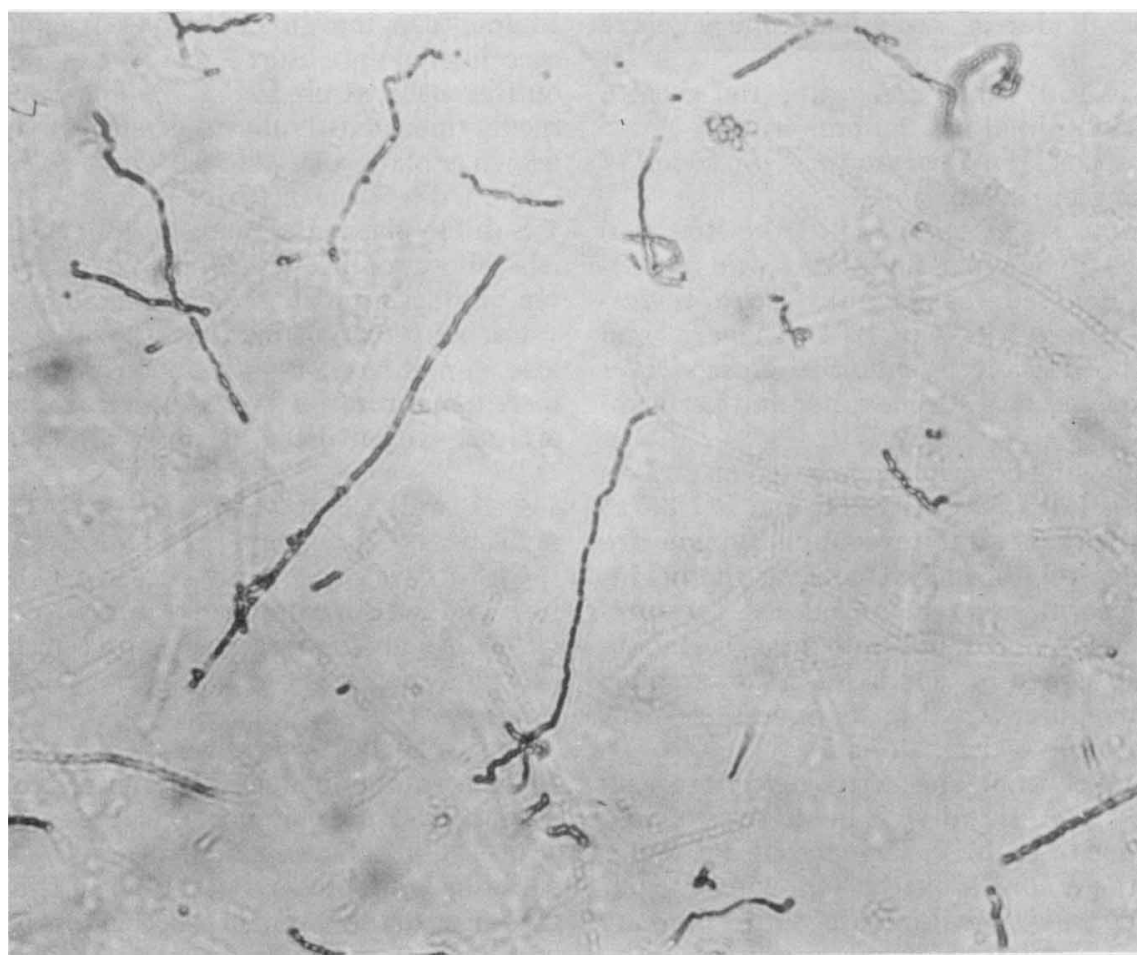

Fig. 3. Nocardiopsis dassonvillei IMRU 509. Sparse hyphae of sporulating aerial mycelium. Fragmenting hyphae of substrate mycelium. Bennett agar. Magnification, $\times 480$.

reproduce by fragmentation of all their hyphae or of more or less accidentally involved parts of them."

On the other hand, whole-cell hydrolysates of Actinomadura species contain madurose, a diagnostically useful sugar which is lacking in $A$. dassonvillei. Therefore, the inclusion of $A$. dassonvillei in the genus Actinomadura Lechevalier and Lechevalier no longer seems suitable.

Although nocardioform behavior might suggest a connection with the genus Nocardia, it must be stressed that, according to McClung (18), members of the family Nocardiaceae have cell walls of type IV; e.g., the genus Nocardia is characterized by cell wall type IV (consisting of meso-2,6-diaminopimelic acid [meso-DAP], arabinose, and galactose) and additionally, according to Lechevalier et al. (16), by the occurrence of nocardomycolic acids. However, $A$. dassonvillei has a cell wall of type III/C (i.e., meso-DAP acid without diagnostically important carbohydrates [12]). Nocardomycolic acids are absent. Any macroscopic resemblance which A. dassonvillei might have to members of the genus Streptomyces (cf. Gordon and Horan [8]) is also offset by the difference in their cell wall types (streptomycetes have cell walls of type I).
Thus, it can be concluded that the organism under study does not have characteristics that would permit its inclusion in any of the genera of the order Actinomycetales recognized by Gottlieb (9) in Bergey's Manual of Determinative Bacteriology (8th ed.) nor does it belong to any recently described genus of this order. For the reasons mentioned above, $A$. dassonvillei is considered to belong to a new genus, for which the name Nocardiopsis is proposed.

Nocardiopsis gen. nov. (no.car.di.op'sis. M.L. fem.n. Nocardia a genus of the order Actinomycetales; G. noun opsis appearance; M.L. fem.n. Nocardiopsis that which has the appearance of Nocardia).

Aerobic, gram-positive, non-acid-fast, catalase-positive actinomycetes. Colonies on organic media are abundant and are coarsely wrinkled or folded. Substrate mycelium is well developed; hyphae are long and densely branched and fragment into coccoid elements. Aerial mycelium is usually well developed and abundant. Hyphae are long, moderately branching, and straight or irregularly curved and completely fragment into spores. Melanoid pigments are not produced. The cell wall contains meso-DAP but no diagnostically important carbohydrates. Whole-cell hydrolysates do 
not contain madurose; nocardomycolic acids are absent.

Found in soil, mildewed grain, and clinical materials of animal and human origin.

Type species: Nocardiopsis dassonvillei (Brocq-Rousseu) comb. nov.

Nocardiopsis dassonvillei (Brocq-Rousseu) comb. nov. [Synonyms: Streptothrix dassonvillei Brocq-Rousseu (basionym); Nocardia dassonvillei (Brocq-Rousseu 1904) Liegard and Landrieu 1911; Actinomadura dassonvillei (Brocq-Rousseu 1904) Lechevalier and Lechevalier 1970.]

(The following description is based on strains IMET 9563, IMRU 509, RG 714, and RG 1250.)

Morphology. Aerial mycelium hyphae are long, moderately branched, and, at the beginning of sporulation, more or less zig-zagshaped; they then divide into long segments which subsequently subdivide into smaller spores of irregular size (Fig. 2). Spores are elongated and smooth (Fig. 4 and 5).

Aerial mycelium. The aerial mycelium varies from a sparse (hardly visible to the unaided eye) coating to a thick, farinaceous to woolly cover of the colonies on the following media: oatmeal agar, oatmeal-nitrate agar, Bennett agar, Czapek-sucrose agar, inorganic saltstarch agar, yeast extract-malt extract agar, and complex organic medium 79. The color of the aerial mycelium is white or yellowish to grayish (color code W1-Co 7a, Cr7a - Co6b of Prauser [24]).

Substrate mycelium. Colonies have dense, filamentous margins. Hyphae fragment into coccoid elements after 3 to 4 weeks, depending on the medium used (Fig. 3). The color on the media mentioned above is either yellowishbrown or olive-colored to dark brown (color code Co6a, Co5b, Co5s or 07r of Prauser [24]).

Soluble pigments. None or yellowish, greenish-yellow, or brown. Melanoid pigments are not produced on ISP 6 or tyrosine agar.

Carbohydrate utilization. L-Arabinose, $\mathrm{D}$-xylose, D-mannose, D-glucose, L-rhamnose, maltose, D-mannitol, D-fructose, sucrose, and glycerol are well utilized by all strains (see Table 1).

Cell wall components. Meso-DAP; no diagnostically important carbohydrate.

Cultures of Brocq-Rousseu's strains on which he based the description of Streptothrix dassonvillei are no longer extant, and it therefore becomes necessary to designate a neotype strain for this species.

Brocq-Rousseu's description of $S$. dassonville $i$ was rather meager: "Diameter of the filaments $0.5-1 \mu$, color of the colonies on potatoes white, gelatin liquefaction positive . . . condensation of protoplasm at the end of the hyphae gives rise to the origin of spore chains (centripetal)which resemble beads, spores are oval, comparable to a big bacillus . . " Gelatin liquefaction by the strains reported in the present study was variable, and although Gordon and Horan (8) reported the production of a yellowish, greenish-yellow, or brown soluble pigment and Goodfellow (6) reported the production of an

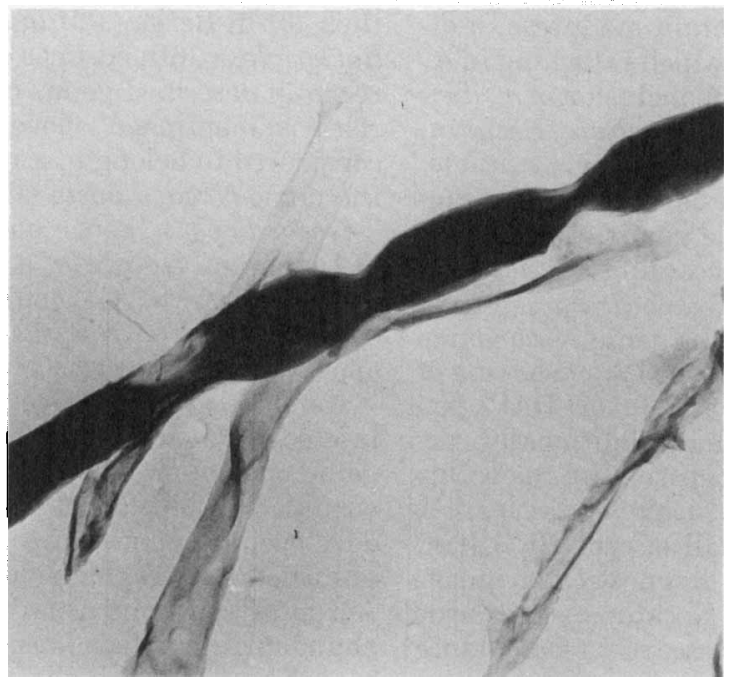

Fig. 4. Nocardiopsis dassonvillei IMRU 509. Electron micrograph of sporulating aerial hyphae. Magnification, $\times 16,500$. 


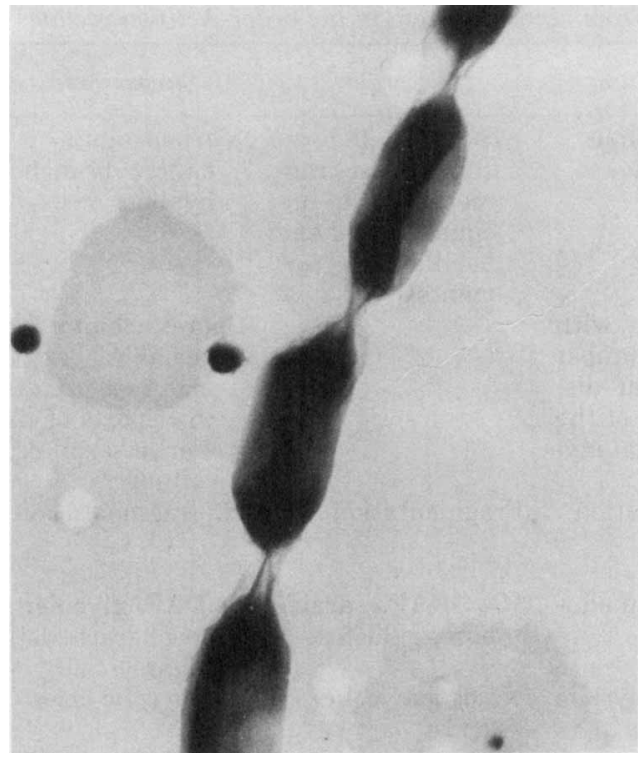

FIG. 5. Nocardiopsis dassonvillei RG 1250. Electron micrograph of sporulating aerial hyphae. Magnification, $\times 16,500$.

exopigment by the strains of this organism that they studied, the strains studied here did not produce a soluble pigment.

Strain IMRU 509 (= ATCC 23218) is here designated as the neotype strain of Nocardiopsis dassonvillei because it possesses in general the characters of this organism given by BrocqRousseu and because Lechevalier (13) had previously selected this strain to be the reference strain for Actinomadura dassonvillei.

Description of the neotype strain. The aerial mycelium is sparse (hardly visible to the unaided eye) on the following media: Czapeksucrose-agar, yeast extract-malt extract agar, Bennett agar, oatmeal agar, oatmeal-nitrate agar, and complex organic medium 79. The hyphae are straight or somewhat coiled; at the beginning of sporulation they are more or less zig-zag shaped; they fragment into longer segments which subdivide into spores of irregular size. Spores are elongated and smooth. Hyphae of the substrate mycelium fragment into coccoid elements after 3 to 4 weeks. Cultures grown on the media mentioned above are macroscopically abundant and coarsely wrinkled. The reverse side of the mycelium is yellowish to yellowish-brown. There is no production of soluble pigment. The physiological reactions of this strain are given in Table 2 .

The characters which differentiate Nocardiopsis from similar genera of the order Actino- mycetales are listed in Table 3 . The borderline between Nocardiopsis and Nocardia is drawn primarily by biochemical criteria: Nocardia is characterized by cell wall type IV (meso-DAP, arabinose, and galactose), the presence of no-

TABLE 1. Carbohydrate utilization by strains of Nocardiopsis dassonvillei

\begin{tabular}{lllll}
\hline & \multicolumn{5}{c}{ Utilization by $N$. dassonvillei } \\
strain: \\
\cline { 2 - 5 } \multicolumn{1}{c}{ Substrate } & IMET & IMRU & RG & RG \\
& 9563 & 509 & 719 & 1250 \\
\hline L-Arabinose & $++^{a}$ & ++ & + & ++ \\
D-Xylose & ++ & ++ & + & ++ \\
D-Mannose & ++ & ++ & + & ++ \\
D-Glucose & ++ & ++ & ++ & ++ \\
L-Rhamnose & ++ & ++ & + & ++ \\
Maltose & ++ & ++ & ++ & ++ \\
D-Mannitol & ++ & ++ & ++ & ++ \\
D-Fructose & ++ & ++ & ++ & ++ \\
Lactose & ++ & + & + & ++ \\
Adonitol & + & - & - & - \\
Dulcitol & + & - & - & \pm \\
$i$-Inositol & ++ & - & \pm & - \\
Sucrose & ++ & ++ & ++ & ++ \\
Raffinose & ++ & \pm & \pm & - \\
Glycerol & ++ & ++ & ++ & ++ \\
Basal medium & - & - & - & - \\
\hline
\end{tabular}

${ }^{a}$ Results recorded by the method of the International Streptomyces Project (32): ++, strongly positive utilization, i.e., growth on the tested carbohydrate in basal medium is equal to or greater than the growth on basal medium plus glucose; + , positive utilization, i.e., growth on the tested carbohydrate is significantly better than that on the basal medium without carbohydrate but somewhat less than that on glucose; \pm , utilization doubtful, i.e., growth on the tested carbohydrate is only slightly better than that on the basal medium without carbon and significantly less than that with glucose; - , utilization negative, i.e., growth is similar to or less than the growth on basal medium without carbohydrate.

TABLE 2. Physiological properties of strains of Nocardiopsis dassonvillei

\begin{tabular}{|c|c|c|c|c|}
\hline \multirow{2}{*}{ Physiological property } & \multicolumn{4}{|c|}{$\begin{array}{c}\text { Reaction by } N \text {. dassonvillei } \\
\text { strain: }\end{array}$} \\
\hline & $\begin{array}{l}\text { IMET } \\
9563\end{array}$ & $\begin{array}{l}\text { IMRU } \\
509\end{array}$ & $\begin{array}{l}\mathrm{RG} \\
714\end{array}$ & $\begin{array}{c}\mathrm{RG} \\
1250\end{array}$ \\
\hline Starch hydrolysis & + & + & + & + \\
\hline Nitrite from nitrate & - & + & + & + \\
\hline Gelatin liquefaction & + & - & \pm & \pm \\
\hline Milk peptonization & + & + & + & + \\
\hline $\begin{array}{l}\text { Decomposition of escu- } \\
\text { lin }\end{array}$ & + & + & + & + \\
\hline $\begin{array}{l}\text { Decomposition of xan- } \\
\text { thine }\end{array}$ & + & + & + & + \\
\hline
\end{tabular}


TABLE 3. Characters which differentiate Nocardiopsis from similar genera of the order Actinomycetales

\begin{tabular}{|c|c|c|c|c|}
\hline $\begin{array}{l}\text { Differentiating charac- } \\
\text { ters }\end{array}$ & Nocardiopsis & Actinomadura & Nocardia & Streptomyces \\
\hline $\begin{array}{l}\text { Morphology of aer- } \\
\text { ial mycelium }\end{array}$ & $\begin{array}{l}\text { Long, scarcely } \\
\text { branched hyphae }\end{array}$ & $\begin{array}{l}\text { Various; hyphae } \\
\text { abundantly } \\
\text { branched }\end{array}$ & $\begin{array}{l}\text { Absent or, if pres- } \\
\text { ent, hyphae frag- } \\
\text { menting into un- } \\
\text { equal coccoid and } \\
\text { bacillary ele- } \\
\text { ments }\end{array}$ & $\begin{array}{l}\text { Various; abun- } \\
\text { dantly branched } \\
\text { hyphae }\end{array}$ \\
\hline Type of sporulation & $\begin{array}{l}\text { Complete sporula- } \\
\text { tion (fragmenta- } \\
\text { tion), often zig- } \\
\text { zag shaped }\end{array}$ & $\begin{array}{l}\text { Spore chains with } \\
\text { limited number } \\
\text { of spores at dis- } \\
\text { tinct parts of the } \\
\text { sterile aerial my- } \\
\text { celium }\end{array}$ & & $\begin{array}{l}\text { Spore chains of } \\
\text { variable length } \\
\text { and type at dis- } \\
\text { tinct parts of the } \\
\text { sterile aerial my- } \\
\text { celium }\end{array}$ \\
\hline $\begin{array}{l}\text { Morphology of sub- } \\
\text { strate mycelium }\end{array}$ & Fragmentation & No fragmentation & Fragmentation & No fragmentation \\
\hline \multirow[t]{2}{*}{ Cell wall type ${ }^{a}$} & III/C & III/B & IV & I \\
\hline & $\begin{array}{l}\text { Meso-DAP, no } \\
\text { characteristic } \\
\text { sugar }\end{array}$ & $\begin{array}{l}\text { Meso-DAP, madu- } \\
\quad \text { rose }\end{array}$ & $\begin{array}{l}\text { Meso-DAP, arabi- } \\
\text { nose, galactose }\end{array}$ & $\begin{array}{l}\text { LL-DAP, glycine, } \\
\text { no characteristic } \\
\text { sugar }\end{array}$ \\
\hline Cell wall lipid & $\begin{array}{l}\text { No nocardomycolic } \\
\text { acids }^{b}\end{array}$ & $\begin{array}{l}\text { No nocardomycolic } \\
\text { acids }^{b}\end{array}$ & $\begin{array}{l}\text { Nocardomycolic } \\
\text { acids }^{c}\end{array}$ & No mycolic acids ${ }^{c}$ \\
\hline $\begin{array}{l}\text { Susceptibility to ly- } \\
\text { sozyme }\end{array}$ & Susceptible $^{d}$ & Susceptible $^{d}$ & Resistant $^{d}$ & Variable $^{e}$ \\
\hline
\end{tabular}

${ }^{a}$ Classification of Lechevalier and Lechevalier (12).

${ }^{b}$ D. Tille, personal communication; cf. also Mordarska et al. (19).

${ }^{c}$ Lechevalier et al. (16).

${ }^{d}$ Results of J. Meyer.

e Gordon (7).

cardomycolic acids, and the resistance to lysozyme; Nocardiopsis, on the other hand, is characterized by cell-wall type III/C (meso-DAP and the absence of diagnostically important carbohydrates), the absence of nocardomycolic acids, and susceptibility to lysozyme.

With regard to the genus Actinomadura, there is no morphological similarity to Nocardiopsis. The nocardioform life cycle of Nocardiopsis represents a striking difference to the stable substrate mycelium and the mode of sporulation in the genus Actinomadura, which is characterized by spore-chain formation at distinct parts of the aerial mycelium, development of sporophores, a more or less limited number of spores per chain, and additionally by the presence of madurose in whole-cell hydrolysates.

The distinction between Nocardiopsis and Streptomyces is based upon morphological and biochemical criteria. The genus Streptomyces is characterized by cell wall type I (LL-2,6-diaminopimelic acid [LL-DAP], glycine, without diagnostically important carbohydrates), which until now has been confined to the family Streptomycetaceae and the newly described genus Nocardioides Prauser (26). Morphologically, the genus Nocardiopsis is well differentiated by its nocardioform life cycle from the genus Strepto-
TABLE 4. Comparison of the properties of Nocardiopsis with those of other genera in the family Thermomonosporaceae

\begin{tabular}{|c|c|c|c|}
\hline Genus & $\begin{array}{l}\text { Kind of sporula- } \\
\text { tion of the aerial } \\
\text { mycelium }\end{array}$ & $\begin{array}{l}\text { Cell } \\
\text { wall } \\
\text { type }\end{array}$ & $\begin{array}{l}\text { Addi- } \\
\text { tional di- } \\
\text { agnostic } \\
\text { criteria }\end{array}$ \\
\hline Nocardiopsis & Total & III & \\
\hline $\begin{array}{l}\text { Thermomono- } \\
\text { spora }\end{array}$ & $\begin{array}{l}\text { Spores occur } \\
\text { singly }\end{array}$ & III & \\
\hline Microbispora & $\begin{array}{l}\text { Spores occur in } \\
\text { pairs }\end{array}$ & III & $\begin{array}{l}\text { Madu- } \\
\text { rose }\end{array}$ \\
\hline Microtetraspora & 4 Spores/chain & $\mathrm{III}^{a}$ & \\
\hline Actinomadura & $>4$ Spores/chain & III & $\begin{array}{l}\text { Madu- } \\
\text { rose }\end{array}$ \\
\hline
\end{tabular}

${ }^{a}$ According to Thiemann et al. (33), the cell walls of Microtetraspora glauca and $M$. fusca contain the unusual combination of meso = DAP, lysine, glycine, and a trace of LL-DAP. Nonomura and Ohara (22) reported type III cell walls for Microtetraspora niveoalba and $M$. viridis.

myces, which is characterized by a well-differentiated aerial mycelium, i.e., sporulation at distinct parts of the aerial mycelium and formation of various types of spore chains. As to the placement of the genus Nocardiopsis in one of the Actinomycetales families, the following proposal can only be considered preliminary: the new genus Nocardiopsis should be placed in the 
family Thermomonosporaceae Cross and Goodfellow (4), which comprises actinomycetes with cell wall type III and with heat-sensitive spores which are enclosed within a thin fibrous sheath. The substrate mycelium may exhibit fragmentation. This taxonomic position is unsatisfactory, indeed, because Thermomonosporaceae at this time is a family of convenience which includes organisms with relatively few similarities (see Table 4). However, there is no other choice at present, and the problem is open for discussion.

\section{ACKNOWLEDGMENTS}

I am indebted to R. E. Gordon, Institute for Microbiology, Rutgers, The State University, New Brunswick, N. J., for providing the reference strains used in this investigation and to D. Tille, Zentralinstitut für Mikrobiologie und experimentelle Therapie, Forschungszentrum für Molekularbiologie und Medizin, Akademie der Wissenschaften der DDR, Jena, for performing the lipid analysis of the cell walls.

\section{LITERATURE CITED}

1. Becker, B., M. P. Lechevalier, R. E. Gordon, and H. A Lechevalier. 1964. Rapid differentiation between $\mathrm{No}$ cardia and Streptomyces by paper chromatography of whole cell hydrolysates. Appl. Microbiol. 12:421-423.

2. Brocq-Rousseu, D. 1904. Sur un Streptothrix. Rev. Gen. Bot. 16:219-230.

3. Buchanan, R. E., J. G. Holt, and E. F. Lessel. 1966. Index Bergeyana. The Williams \& Wilkins Co., Baltimore.

4. Cross, T., and M. Goodfellow. 1973. Taxonomy and classification of the actinomycetes, p. 11-112. In G. Sykes and F. A. Skinner (ed.), Actinomycetales: characteristics and practical importance. Academic Press Inc., New York.

5. Gause, G. F., T. S. Maksimova, O. L. Olkhovatova, M. A. Sveshnikova, G. V. Kochetkova, and G. B. Ilchenko. 1974. Production of madumycin, an antibacterial antibiotic, by Actinomadura flava sp. n. Antibiotiki 19:771-774.

6. Goodfellow, M. 1971. Numerical taxonomy of some nocardioform bacteria. J. Gen. Microbiol. 69:33-80.

7. Gordon, R. E. 1966 . Some criteria for the recognition of Nocardia madurae (Vincent) Blanchard. J. Gen. Microbiol. 45:355-364.

8. Gordon, R. E., and A. C. Horan. 1968. Nocardia dassonvillei, a macroscopic replica of Streptomyces griseus. J. Gen. Microbiol. 50:235-240.

9. Gottlieb, D. 1974. Actinomycetales Buchanan 1917, p. 651-659. In R. E. Buchanan and N. E. Gibbons (ed.), Bergey's manual of determinative bacteriology, 8th ed. The Williams and Wilkins Co., Baltimore.

10. Lavrova, N. V., and T. P. Preobrazhenskaya. 1975. Isolation of new species of Actinomadura on selective media with rubomycin. Antibiotiki 20:483-488.

11. Lavrova, N. V., T. P. Preobrazhenskaya, and M. A. Sveshnikova. 1972. Isolation of soil actinomycetes on selective media with rubomycin. Antibiotiki 17:965970.

12. Lechevalier, H. A., and M. P. Lechevalier. 1970. Chemical composition as a criterion in the classification of aerobic actinomycetes. Int. J. Syst. Bacteriol. 20:435443.

13. Lechevalier, H. A., and M. P. Lechevalier. 1970. A critical evaluation of the genera of aerobic actinomycetes, p. 393-405. In H. Prauser (ed.), The Actinomycetales. VEB Gustav Fischer Verlag, Jena.
14. Lechevalier, H. A., M. P. Lechevalier, and N. N. Gerber. 1971. Chemical composition as a criterion in the classification of actinomycetes. Adv. Appl. Microbiol. 14:47-72.

15. Lechevalier, M. P. 1968. Identification of aerobic actinomycetes of clinical importance. J. Lab. Clin. Med. 71:934-944.

16. Lechevalier, M. P., A. C. Horan, and H. A. Lechevalier. 1971. Lipid composition in the classification of nocardiae and mycobacteria. J. Bacteriol. 105:313318.

17. Liegard, H., and M. Landrieu. 1911. Un cas de mycose conjunctivale. Ann. Ocul. 146:418-426.

18. McClung, N. M. 1974. Nocardiaceae Castellani and Chalmers 1919, p. 726-746. In R. E. Buchanan and N. E. Gibbons (ed.), Bergey's manual of determinative bacteriology, 8th ed. The Williams and Wilkins Co., Baltimore.

19. Mordarska, H., M. Mordarski, and M. Goodfellow. 1972. Chemotaxonomic characters and classification of some nocardioform bacteria. J. Gen. Microbiol. 71:77-86.

20. Mund, C., and H. Venner. 1964. Einfache Methode zur Bausteinanalyse von Polysacchariden, Proteinen und deren Komplexen. Hoppe-Seyler's Z. Physiol. Chem. 338:145-153.

21. Murray, J. G., and A. G. J. Proctor. 1965. Paper chromatography as an aid to the identification of Nocardia species. J. Gen. Microbiol. 41:163-167.

22. Nonomura, H., and Y. Ohara. 1971. Distribution of actinomycetes in soil. IX. New species of the genera Microbispora and Microtetraspora and their isolation method. J. Ferment. Technol. 49:887-894

23. Nonomura, H., and Y. Ohara. 1971. Distribution of actinomycetes in soil. XI. Some new species of the genus Actinomadura Lechevalier et Lechevalier. J. Ferment. Technol. 49:904-912.

24. Prauser, H. 1964. Aptness and application of colour codes for exact description of colours of streptomycetes. Z. Allg. Mikrobiol. 4:95-98.

25. Prauser, H. 1975 The Actinomycetales - an order?, p 19-33. In T. Hasegawa (ed.), Proceedings of the First Intersectional Congress of the International Association of Microbiological Societies. Science Council of Japan, Tokyo.

26. Prauser, H. 1976. Nocardioides, a new genus of the order Actinomycetales. Int. J. Syst. Bacteriol. 26:5865.

27. Prauser, H., and M. Bergholz. 1974. Taxonomy of actinomycetes and screening for antibiotic substances. Postepy Hig. Med. Dośw. 28:441-457.

28. Prauser, H., and R. Falta. 1968. Phagensensibilität, Zellwandzusammensetzung und Taxonomie von Actinomyceten. Z. Allg. Mikrobiol. 8:39-46.

29. Preobrazhenskaya, T. P., N. V. Lavrova, and N. O. Blinov. 1975. On the taxonomic position of Streptomyces luteofluorescens. Mikrobiologiya 44:524-527.

30. Preobrazhenskaya, T. P., N. V. Lavrova, R. S. Ukholina, and N. P. Nechaeva. 1975. Isolation of new species of Actinomadura on selective media with streptomycin and bruneomycin. Antibiotiki 20:404-409.

31. Preobrazhenskaya, T. P., and M. A. Sveshnikova. 1974. New species of the Actinomadura genus. Mikrobiologiya $43: 864-868$.

32. Shirling, E. B., and D. Gottlieb. 1966. Methods for characterization of Streptomyces species. Int. J. Syst. Bacteriol. 16:313-340.

33. Thiemann, J. E., H. Pagani, and G. Beretta. 1968. A new genus of the Actinomycetales: Microtetraspora gen. nov. J. Gen. Microbiol. 50:295-303.

34. Williams, S. T., G. P. Sharples, and R. M. Bradshaw. 1974. Spore formation in Actinomadura dassonvillei (Brocq-Rousseu) Lechevalier and Lechevalier. J. Gen. Microbiol. 84:415-419. 